УДК 164:005:334

JEL M11, M29, P11

DOI 10.31375/2226-1915-2020-4-45-

Ю.Є. Прихно

кандидат технічних наук, дочент кафедри

«Уравління

логістичними системами та проектами» ORCID https://orcid.org/0000-0002-6415-8232 e-mailprykhnojulia@gmail.com

Одеський національний морський університет

\section{ІНВЕСТИЦИЙНІ ПРОЕКТИ} В ЛОГІСТИЧНИХ СИСТЕМАХ

Анотація. Одним з ключових чинників економічного та інноваційного розвитку держави $\epsilon$ висока активність реалізацї інвестиційних проєктів, щзо сприяє забезпеченню економічного росту $i$, як наслідок, підвищенню добробуту суспільства. Вона знаходить своє вираження в інвестиційній діяльності логістичних систем.

Однак, перехід від традичійно сформованих виробничих систем до логістично організованих неможливий без дотримання як основоположних принципів управління логістичними системами, так і проєктних принципів. При формуванні логістичних систем, а також при управлінні рухом сировини, матеріалів, напівфабрикатів, незавершеного виробництва та готової продукиії в иих системах необхідною умовою успішного їх функиіонування є дотримання принцииів логістичного управління потоковими прочесами. Вирішення цих проблем лежить в дотриманні принципів організації виробничо-логістичних прочесів як одного з основних умов ефективної діяльності підприємств. Застосування логістичного та проєктного підходів до розвитку логістичних систем передбачає постановку иілей розвитку $i$ знаходження їх оптимального поєднання; визначення шляхів $i$ засобів досягнення иих иілей через виявлення зв'язків і дослідження взаємодії чинників, щзо враховуються і об'єктів; взаємопов'язування иілей $i$ засобів їх досягнення з потребою в ресурсах, при реалізації інвестиційних проектів.

Таким чином, невирішеність проблеми вдосконалення процесу вибору, реалізації і управління інвестиційними проєктами в логістичних системах, а також недостатнє висвітлення даної проблеми у вітчизняній $i$ зарубіжній літературі $і$ визначають актуальність теми дослідження.

Ключові слова: управління проєктами, логістична концепція, логістична стратегія, інвестиційні проєкти.

\footnotetext{
(C) Прихно Ю.Є., 2020
}

УДК 164:005:334

JEL M11, M29, P11

DOI 10.31375/2226-1915-2020-4-45-

Ю.Е. Прихно

кандидат технических наук, доцент кафедры

«Управление

логистическими системами и проектами»

Одесский национальный морской университет

\section{ИНВЕСТИЦИОННЫЕ ПРОЕКТЫ}

В ЛОГИСТИЧЕСКИХ СИСТЕМАХ

Аннотация. Одним из ключевых факторов экономического $и$ инновачионного развития государства является высокая активность реализаџии инвестиционных проектов, что способствует обеспечению экономического роста $и$, как следствие, повышению благосостояния общества. Она находит свое выражение в инвестиционной деятельности логистических систем.

Однако, переход от традиционно сложившихся производственных систем к логистически организованным невозможен без соблюдения как основополагаюших принципов управления логистическими системами, так и проектных приниипов. При формировании логистических систем, а также при управлении движением сырья, материалов, полуфабрикатов, незавершенного производства $u$ готовой продукиии в этих системах необходимым условием успешного их функционирования является соблюдение принципов логистического управления прочессами. Решение этих проблем лежит в соблюдении принцииов организаџии производственно-логистических прочессов как одного из основополагаюших условий эффективной деятельности предприятий.

Применение логистического и проектного подходов к развитию логистических систем предполагает постановку иелей развития и нахождения их оптимального сочетания; определение путей $u$ средств достижения этих иелей через выявление связей и исследование взаимодействия учитываемых факторов и объектов; взаимоувязку иелей и средств их достижения с потребностью в ресурсах, при реализации инвестиционных проектов.

Таким образом, нерешенность проблемы совершенствования прочесса выбора, реализачии $и$ управления инвестииионными проектами в логистических системах, а также недостаточное освещение данной проблемы в отечественной и зарубежной литературе определяют актуальность темы исследования.

Ключевые слова: управление проектами, логистическая концепция, логистическая стратегия, инвестиционные проекты 
UDC 164:005:334

JEL M11, M29, P11

DOI 10.31375/2226-1915-2020-4-45-

Yuliya Prykhno

PhD, Senior Lecturer, Department of Logistics Systems and Projects Management ORCID https://orcid.org/0000-0002-6415-8232 e-mail prykhnojulia@gmail.com

Odessa National Maritime University, Odessa, Ukraine

\section{INVESTMENT PROJECTS IN LOGISTICS SYSTEMS}

Abstract. Scientists have researched and scientifically substantiated the significant effect of the use of project management tools on all business entities and on the country's economy as a whole. At the same time, in modern conditions active economic development and turbulence environment, lead to the fact that considerable attention should be given to the strategic line of conduct of enterprises. The strategy allows to take into account the capabilities of the enterprise, as well as investment projects in various strategic business areas. Despite the fact that many sources describe the process of the development of logistics systems through investment projects; in practice it is very difficult to implement. For the implementation of investment projects of the enterprise it is necessary to present this process in the form of a set of formalized procedures or in the form of step-by-step sequence of actions for choosing the best option for an investment project.

This problem is especially relevant for logistics systems, because their activities are carried out in the form of many projects.

Increasing the volume of investments and improving the efficiency of investment management in logistics systems is one of the fundamental conditions for reducing the duration of the production and sales cycle, which creates the preconditions for economic growth by accelerating the turnover of funds. The production potential of economic entities, their efficiency, and hence the sectoral and reproductive structure of all public production will largely depend on the investment projects, both at the micro and at the macro logistical level.

Unsolved in practical terms of the problem of improving the investment process and management of investment activities in logistics systems, the need to develop a methodology for analyzing and modeling the investment activities of logistics systems in the context of the transformation of the economy, as well as insufficient coverage of this problem in domestic and foreign literature determined the relevance of the research topic.

Keywords: project management, logistic concept, logistic strategy, investment projects.

Постановка проблеми. Одним 3 ключових чинників економічного розвитку держави $\epsilon$ інвестиційна активність в різних галузях виробництва. Вона сприяє забезпеченню економічного росту не тільки підпри- 
DEVELOPMENT OF MANAGEMENT

AND ENTREPRENEURSHIP METHODS ON TRANSPORT, № 4 (73), 2020
РОЗВИТОК МЕТОДІВ

УПРАВЛІННЯ ТА ГОСПОДАРЮВАННЯ

НА ТРАНСПОРТІ, № 4 (73), 2020 ємства або сфери, але й розвитку суміжних сфер, та держави в цілому. Як наслідок, така активність знаходить своє вираження в інвестиційній діяльності логістичних систем.

Зрозуміло, що збільшення інвестицій та підвищення ефективності управління інвестиційною діяльністю в логістичних системах, $є$ одним 3 основних умов скорочення тривалості виробничо-збутового циклу, що створює передумови для економічного зростання. Від ефективного управління інвестиційними проєктами як на мікро, так i на макрологістичному рівні багато в чому залежить виробничий потенціал господарюючих суб'єктів, ефективність їх функціонування, а значить галузева i відтворювальна структура всього суспільного виробництва.

Огляд останніх публікацій та досліджень. Значний внесок у розробку різних аспектів проблем інвестиційних проектів та управління ними було зроблено такими вченими, як С.Д. Бушуєвим, Н.С. Бушуєвою, І.О.Лапкіною, С.К.Черновим, І.А. Бабаєвим, B.I. Воропаєвим, В.O. Іріковим, I.I. Мазуром, Х. Танакою, В.Н. Треньовим, В.Д. Шапіро, та ін.

У [1] розглядається матеріальний потік, як основа логістичних операцій, розглядається розвиток логістичних систем, однак логістичні системи не розглядаються в контексті залучення до них інструментів управління проектами. Не висвітлено інвестиційні проекти та процеси, які пов'язані з логістичними системами.
У [2] розглядається логістична система та ресурси. Автори доходять висновку, що ресурси - підсистема логістичної системи, доводять, що ресурси повинні бути логістично керованими, але не розглядається розвиток логістичної системи на базі ресурсно-орієнтованого підходу.

У [3] розглянуто можливість застосування методології управління проектами до управління логістичною системою. Розглядаються логістичні системи у загальному вигляді, однак, не розглядаються інвестиційні проекти та процеси в логістичних системах. Автор розглядає логістичний та проектний підходи до розвитку логістичних систем, однак, не приділяє увагу інвестиційним проектам, як ефективному способу розвитку логістичної системи.

Таким чином, у більшості досліджень увагу приділено проблемі оцінки ефективності інвестицій. Однак залишається недостатньо вивченою проблема формування варіантів інвестиційних проектів в логістичних системах.

Так, створена теоретична база дозволяє вирішувати проблеми, пов'язані 3 інвестиційним проектуванням однак, оцінка складу i структури інвестиційних проектів логістичних систем є недостатньо дослідженою.

Завдання дослідження. Зміст, процедура та форми реалізації інвестиційних проектів залежать від характеру економічної системи, в якій вони здійснюються, що багато в чому і визначає ступінь проникнення методології управління проектами в ло- 
DEVELOPMENT OF MANAGEMENT

AND ENTREPRENEURSHIP METHODS ON TRANSPORT, № 4 (73), 2020
РОЗВИТОК МЕТОДІВ

УПРАВЛІННЯ ТА ГОСПОДАРЮВАННЯ

НА ТРАНСПОРТІ, № 4 (73), 2020 гістику. Характер ринкового розвитку сучасної логістики привів до того, що подальше розширення складу пропонованих логістичних операцій, призводить до зниження загальної рентабельності комплексу пропонованих логістичних послуг. Саме тому догістичні системи потребують нових ефективних методів вирішення проблем, якими можуть стати методи управління проектами у синергії 3 логістичним підходом.

Основний матеріал дослідження. Застосування логістичного та проектних підходів до розвитку економічних систем передбачає вирішення наступних завдань:

- постановка цілей розвитку i знаходження їх збалансованого поєднання;

- визначення шляхів і засобів досягнення поставленнях цілей через виявлення зв'язків i дослідження взаємодії чинників системи;

- взаємна ув'язка цілей і засобів ïх досягнення з потребою в ресурсах.

При логістичному підході управляючі дії формуються, виходячи із цілей досліджуваної системи та додаються з боку єдиної логістичної системи управління до нового об'єкту управління - наскрізного матеріального потоку.

Новизна логістичного підходу полягає в зміні пріоритетів між різними видами господарської діяльності на користь посилення важливості діяльності 3 управління наскрізним матеріальним потоком. Виділення матеріального потоку, в якості об'єкта управління, дозволяє проекту- вати наскрізні логістичні ланцюги, вирішувати завдання наскрізного моніторингу руху вантажів, починаючи від первинного джерела сировини через всі проміжні процеси аж до надходження до кінцевого споживача, i, в цілому, відкриває нові можливості дослідження економічних процесів.

Таким чином, принципова відмінність логістичного підходу до управління матеріальним потоком від традиційного полягає:

1) в об'єднанні розрізнених матеріальних потоків в єдиний наскрізний матеріальний потік;

2) у виділенні єдиної функції управління наскрізним матеріальним потоком;

3) у технічній, економічній, інформаційній інтеграції бізнес-одиниць до єдиної системи.

Логістичний підхід обумовлює необхідність впровадження системи управління i контролю за рухом i використанням всієї номенклатури продукції, що надходить у виробництво, а також готових виробів, що доставляються споживачеві. Найважливіша особливість зазначеного підходу - побудова системи управління, при якій матеріальний потік не поділяється на кілька функціональних блоків (постачання, виробництво, збут, транспортування, зберігання та ін.), а розглядається і управляється як єдине ціле, за загальними для всієї логістичної системи категоріями.

Управлінські функції при такому підході будуються на основі тісної ув'язки постачальницьких, збутових i виробничих планів, графіків роботи 
DEVELOPMENT OF MANAGEMENT

AND ENTREPRENEURSHIP METHODS ON TRANSPORT, № 4 (73), 2020
РОЗВИТОК МЕТОДІВ

УПРАВЛІННЯ ТА ГОСПОДАРЮВАННЯ

НА ТРАНСПОРТІ, № 4 (73), 2020 транспорту, пов'язаних 3 рухом готових виробів в ході закупівельних i збутових операцій. Для виконання таких скоординованих функцій на підприємствах зазвичай створюється нова система управління виробничими процесами, спрямована на забезпечення заданого рівня обслуговування споживачів, що не допускає збільшення витрат на зберігання i переміщення сировини, матеріалів, незавершеної продукції і готових виробів на основі координації дій постачальницьких, виробничих і збутових ланок.

В якості головних інструментів логістичний підхід передбачає аналіз і синтез досліджуваної системи. Аналіз системи дозволяє виявити найбільш істотні фактори, дає їх характеристику, кількісну оцінку взаємодії один 3 одним, визначає вплив їх на параметри досліджуваної системи. Синтез забезпечується в процесі розробки і функціонування формалізованої моделі досліджуваних параметрів системи.

Передумовами для логістичного підходу є:

- нове розуміння механізмів ринку i логістики як стратегічного елемента в реалізації і розвитку конкурентних можливостей підприємств і системи в цілому;

- реальні перспективи і сучасні тенденції щодо інтеграції учасників господарських зав'язків між собою;

- технологічні можливості в області інформаційних технологій, які відкривають принципово нові можливості для взаємодії учасників системи, зниження витрат i раціонального розподілу ресурсів.

Однією 3 найважливіших умов ефективного управління та розвитку логістичних систем $\epsilon$ забезпечення потреби в фінансових ресурсах. Найкращим інструментом у вирішенні цієї проблеми є залучення інвестицій.

Здійснення інвестицій в розвиток логістичних систем характеризується рядом особливостей:

1. Інвестування $є$ головною формою реалізації стратегії розвитку, як конкретного підприємства, так і всієї логістичної системи. Основна мета цього розвитку забезпечується здійсненням високоефективних інвестиційних проектів, а сам процес стратегічного розвитку являє собою реалізацію інвестиційних проектів усіма учасниками системи. Саме така форма інвестування дозволяє підприємствам системи в процесі інтеграції 3 іншими іiі учасниками успішно проникати на нові товарні і регіональні ринки, забезпечувати постійне зростання своєї ринкової вартості.

2. Головними завданнями залучення інвестицій в розвиток логістичної системи є:

- збільшення обсягу виробництва і збуту продукції; робів;

- розширення асортименту ви-

- підвищення якості виробів i послуг;

- наближення підприємств до ринків збуту;

- оптимізація транспортних витpaт; 
DEVELOPMENT OF MANAGEMENT

AND ENTREPRENEURSHIP METHODS ON TRANSPORT, № 4 (73), 2020
РОЗВИТОК МЕТОДІВ

УПРАВЛІННЯ ТА ГОСПОДАРЮВАННЯ

НА ТРАНСПОРТІ, № 4 (73), 2020 та ін.

- зниження логістичних витрат

Поняття «інвестиційний проект» в теорії управління проектами розглядається у двох аспектах:

- як діяльність, яка передбачає здійснення комплексу заходів для досягнення поставленої мети (отримання певного результату) - інвестиційний процес;

- як система організаційно-правових та розрахунково-фінансових документів, необхідних для здійснення будь-яких дій або описання цієї дії - інвестиційний бізнес-план.

Інвестиційний процес в управлінні проектами характеризується вибором напрямку підприємницької інвестиційної активності та при проектно-орієнтованому управлінні визначається стратегічними цілями підприємства (рис. 1). Рішення про реалізацію інвестиційних проектів у логістичних системах мають величезне значення, оскільки вони пов'язані 3 використанням великої кількості ресурсів підприємств. Невірні рішення в ході реалізації цих проектів можуть поставити під загрозу не тільки функціонування окремих підприємств, а й функціонування всієї логістичної системи.

Так, процедура формування варіантів інвестиційних проектів логістичної системи повинна бути чітко сформульована. На рис. 1 запропоновано підхід до процедури формування варіантів інвестиційних про- ектів логістичної системи. Такий підхід містить в якості ключових складових традиційні елементи: визначення напрямків інвестиційних проектів логістичної системи (поелементного, функціонального, інтеграційного або нарощування функцій), а також оцінки різних варіантів інвестиційної діяльності в логістичній системі не 3 позиції мінімуму логістичних витрат, а 3 позиції комплексних змін. Такі зміни можуть стосуватися ринкової частки логістичної системи, скорочення витрат ресурсів в логістичних системах, можливих ризиків інвестиційних проектів.

Таким чином, запропонований підхід дозволяє сформувати інвестиційні проекти логістичної системи, відповідно до логістичної стратегії. Це сприяє розвитку конкурентних переваг кінцевого продукту (послуги) та дозволяє поліпшити рівень керованості системи та ефективності використання ресурсів.

Висновки. Визначено, що інвестиційні проекти в логістиці тісно пов'язані із стратегічними цілями, та, як наслідок, процедура формування варіантів інвестиційних проектів логістичної системи повинна бути чітко сформульована. Методи та інструменти управління проектами у синергії 3 логістичною концепцією дають можливість створити стратегію, яка передбачає можливість розвитку усієї логістичної системи через інвестиційні проекти. 


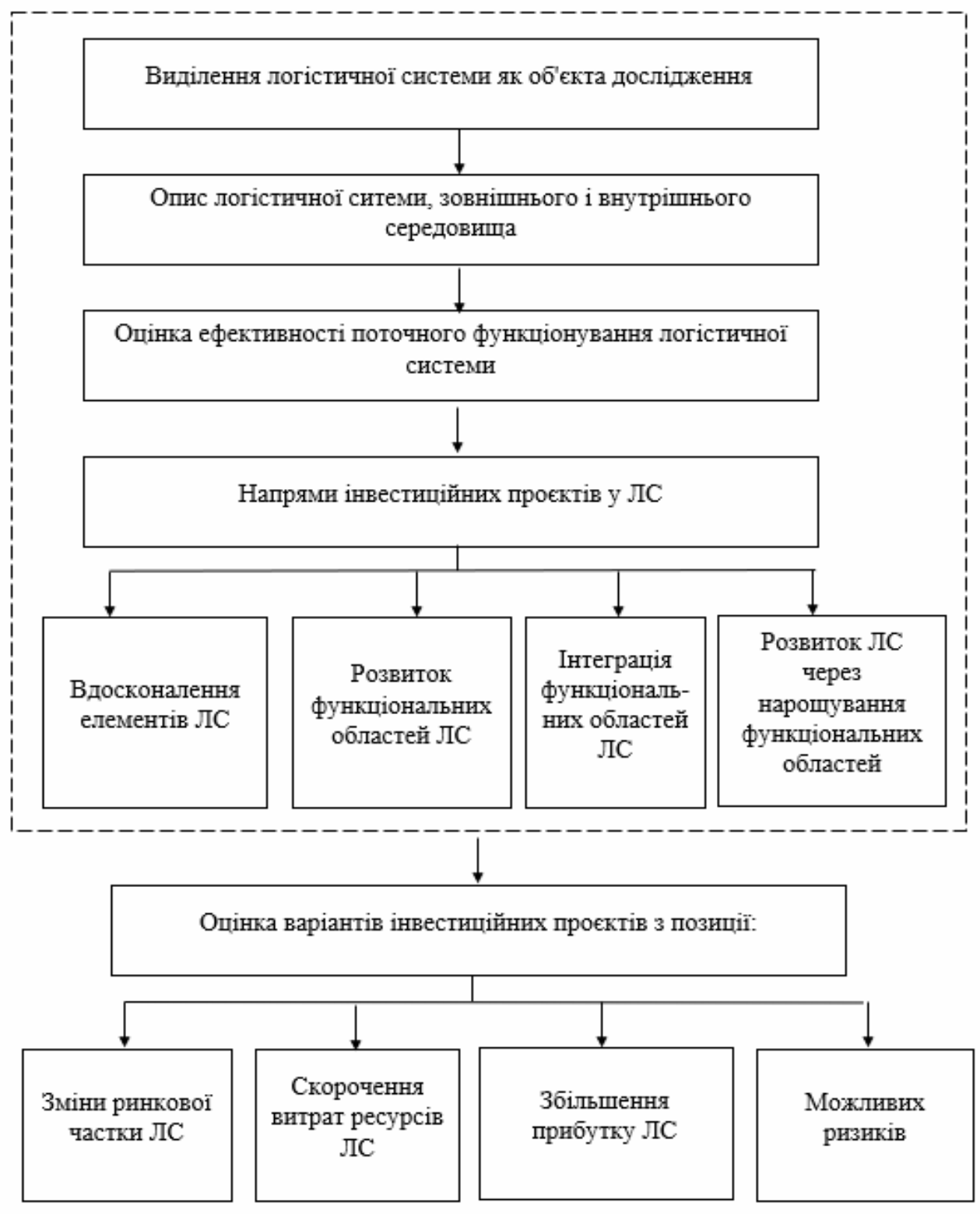

Рис. 1. Проиедура формування варіантів інвестиційних проектів в логістичній системі

Джерело: розроблено автором 


\section{СПИСОК ЛІТЕРАТУРИ}

1. Моисеева Н.К., Сергеев В.И. Экономические основы логистики [Текст]: Учебник. Москва: ИНФРА-М, 2011. 527 с.

2. Лапкина И. А., Поддубная Н. Н. Ресурсы логистической системы [Текст] // Вестник СНУ им. В. Даля. 2015. № 2(219). С. 69-72

3. Paul, R., Murphy, Jr., A. Michael Knemeyer. Contemporary Logistics. Hardcover, Ninth Edition, 2017. 415 p.

4. Кириллова Е.В. Идентификачия транспортно-технологической системы в качестве транспортирующей подсистемы логистической системы // Вісник Одеського національного морського університету. 2015. Bun. 1. C. $128-148$.

5. Бушуев С.Д., Бушуева Н.С. Управление программами развития быстрорастущих компаний. Управленческий консультант. К.: Супремум, 2006. C. 84-114.

6. Бушуев, С.Д. Бушуева Н. С., Бабаев И. А. и др. Креативные технологии в управлении проектами и программами [Текст]. К.: Саммит книга, 2010. $768 \mathrm{c.}$

7. Гаджинский А. М. Логистика: Учебник. М.:ИТК «Дашков и КО», 2012. $484 \mathrm{c}$.

8. A Guidebook of Project \& Program Management for Enterprise Innovation, / Representative Author S. Ohara, published by Project Management Association of Japan: 2005. 87 p.

9. Gerald, I. Kendall, Steven, C. Advanced Project Portfolio Management and the PMO: Multiplying ROI At Warp Speed. PMP.: J Ross Publishing, 2003. $320 \mathrm{p}$.

10. Товб А.С., Ципес Г.Л. Управление проектами: стандарты, методы, опыт [Текст]. 2-е издание. М.: Олимп-Бизнес, 2005. 240 c.

11. Bushuev, S.D., Bushueva, N.S. Development project management maturity for the fast growing innovative company in turbulence environment. Ukrainian case. [Text]: The preceding of 20 IPMA World Congress on Project Management. Shanghai, China. Volume 2. 2006. p. 559-563.

12. Каплан Р., Нортон Д. Стратегическое единство: создание синергии организаиии с помощью сбалансированной системы показателей [Текст]. M.: 2006. 284 c.

13. Лапкина И.А. Проблемы применения проиессного подхода в деятельность коммерческих и некоммерческих организаций // Управління проектами та розвиток виробництва: Зб.наук.пращьь. Луганськ: вид-во СНУ ім. В. Даля, 2006. № 2(18). C. 62-71. 
14. Рач В.А. Стратегический потенцииал предприятия в условиях новой экономики // Управления проектами та розвиток виробництва: Зб.наук.працьь. Луганськ: вид-во СНУ ім. В.Даля, 2002. № 1(4). С.5-9.

\section{REFERENCES}

1. Moiseeva, N.K. \& Sergeev,V.I. (2011). Jekonomicheskie osnovy logistiki [Economical basic of logistic]. Moskva: INFRA-M, 527 [in Russian].

2. Lapkina, I. A. \& Poddubnaya N. N. (2015). Resursy logisticheskoj sistemy [Logistics system resources]. Vestnik CNU im. V. Dalya - Bulletin of SNU named after V. Dahl. № 2(219), 69-72. [in Russian].

3. Paul R. Murphy Jr. , A. Michael Knemeyer. (2017). Contemporary Logistics Hardcover, Ninth Edition, 415 p. [in English]

4. Kirillova, E. V. (2015). Identification of the transport-technological system as a transporting subsystem of the logistic system. Visnik Odeskogo nacionalnogo morskogo universitetu. Vip. 1, 128-148. [in Russian]

5. Bushuev, S.D. \& Bushueva, N.S. (2006). Upravlenie programmami razvitiya byistrorastuschih kompaniy [Management of development programs for highgrowth companies]. Upravlencheskiy konsultant-Management consultant. K.: Supremum, 84-114. [in Russian]

6. Bushuev, S.D., Bushueva, N.S., Babayev, I.A., Yakovenko, V.B., Grisha, E.V., Dziuba, S.V. \& Voitenko, A.S. (2010). Kreativnye tekhnologii v upravlenii proektami i programmami - Creative technologies in project and program management. K.: Summit-Kniga, 768. [in Russian]

7. Gadzhinskij, A.M. (2012). Logistika [Logistic]. M.: Izdatel'sko-torgovaja korporacija "Dashkovi $K^{\circ} », 484$ [in Russian].

8. A Guidebook of Project \& Program Management for Enterprise Innovation (2005). Representative Author S. Ohara, published by Project Management Association of Japan, 87.

9. Gerald I. Kendall, Steven C. (2003). Advanced Project Portfolio Management and the PMO: Multiplying ROI At Warp Speed. PMP. : J Ross Publishing, 320. [in English].

10. Tovb, A.S. \& Tsipes, G.L. (2005). Upravlenie proektami: standarty, metody, opyt [Project management: standards, methods, experience]. Olimp-Busness, 240. [in Russian].

11. Bushuev, S.D. \& Bushueva, N.S. (2006). Development project management maturity for the fast growing innovative company in turbulence environmentUkrainian case. The preceding of 20 IPMA World Congress on Project Management, 2, 559-563. 
12. Kaplan R. \& Norton D. (2006). Strategicheskoe edinstvo, sozdanie sistemi pokazatelei [Strategic unity: creating synergy in the organization with a balanced scorecard]. M: LLC I.D.Williams, 384. [in Russian].

13. Lapkina, I.A. (2006). Problemyi primeneniya protsessnogo podhoda $v$ deyatelnost kommercheskih i nekommercheskih organizatsiy [Problems of the process approach application in profit and non-profit organization activity]. Upravlinnya proektami ta rozvitok virobnitstva - Project management and production development. Lugansk. №2(18), 62-71. [in Russian].

14. Rach, V.A. (2002). Strategicheskiy potentsial predpriyatiya $v$ usloviyah novoy ekonomiki [The strategic potential of the enterprise in the new economy]. Upravlinnya proektami ta rozvitok virobnitstva - Project management and production development. Lugansk № 1(4), 5-9. [in Russian].

Стаття надійшла до редакиії 18.11.2020

Посилання на статтю: Прихно Ю.С. Інвестиційні проекти в логістичних системах // Розвиток методів управління та господарювання на транспорті: Зб. наук. праць, 2020. № 4 (73). C. 45-54. DOI 10.31375/2226-1915-2020-4-45-54.

Article received 18.11.2020

Reference a JournalArtic: Prykhno Yuliya. (2020). Investment projects in logistics systems. Development of management and entrepreneurship methods on transport. 4 (73), 45-54. DOI 10.31375/2226-1915-2020-4-45-54. 